\title{
Canopy-Air Temperature Differences and Soil Water as Predictors of Water Stress of Apple Trees Grown in a Humid, Temperate Climate
}

\author{
Preston K. Andrews ${ }^{1}$, David J. Chalmers ${ }^{2}$, and Mapasaka Moremong ${ }^{3}$ \\ Department of Horticultural Science, Massey University, Palmerston North, New Zealand \\ Additional index words. evapotranspiration, infrared thermometry, Malus domestics, vapor pressure deficit
}

\begin{abstract}
Temperature differences between tree canopies and air $\left(T_{c}-T_{2}\right)$ and between leaves and air $\left(T_{1}-T_{n}\right)$ of apples (Malus domestics Borkh. 'Royal Gala') grown in New Zealand were measured with infrared (IR) thermometry. Treatments included three orchard-floor management systems and irrigation withheld (WI) for part of the growing season. Measurements of soil moisture indicated that, under full irrigation (FI), an alfalfa orchard-floor system apparently had higher soil water content than herbicide-strip $(\mathrm{H})$ or plastic-mulch systems, whereas under the drought stress of WI, the $H$ system retained the most water. The $T_{c}-T_{a}$ and $T_{1}-T_{a}$ of the WI treatment were significantly greater than those of the FI treatment after a soil-moisture differential was established. Linear regression between $T_{c}-T_{a}$, or $T_{1}-T_{a}$, and vapor pressure deficit (VPD) exhibited variable responses among dates. A crop water stress index (CWSI) was calculated from environmental measurements. The calculated CWSIS were not related to soil-moisture measurements. Even 35 days after full irrigation had been reinstated on the WI plots, the $T_{c}-T_{a}$, $T_{1}-T_{a}$, and CWSI of the WI plots were still significantly greater than those of the FI plots. These discrepancies in IR thermometry-based water-stress indices may be due to increased errors in the calculation of minimum CWSI at low VPDS and to fluctuating solar radiation and evapotranspiration, which are prevalent in humid, temperate climates.
\end{abstract}

Plant water status integrates the effects of available soil water, evaporative demand, and the hydraulic fluxes within the soilplant-atmosphere continuum (Chalmers et al., 1983; Jones et al., 1985; Spomer, 1985). Variabilities in soil hydraulic properties, root distribution, and the dynamic nature of hydraulic resistances within fruit trees can result in inaccurate estimates of plant water status by soil water potential-based measurements (Campbell and Campbell, 1982; Jones et al., 1985; Syvertsen, 1985). Measures of current plant water status, e.g., leaf water potential, vary from point to point in the plant (Jackson, 1982). Measurements based on canopy temperatures of cotton (Gossypium hirsutum L.) (Ehrler, 1973) and wheat (Triticum aestivum L.) (Jackson et al., 1977) more effectively assessed plant water status, particularly during the early stages of water stress.

The use of canopy-air temperature differences $\left(T_{c}-T_{a}\right)$ to detect plant moisture stress is based on two assumptions (Jackson, 1982). First, a well-watered crop will transpire at its maximum potential rate, resulting in leaf temperatures lower than air temperature. Second, as water deficits increase, transpiration declines and leaf temperature rises relative to air temperature. The potential for using these relationships for developing a quantitative index of plant water stress for irrigation scheduling in relatively uniform crop canopies was enhanced with the development of IR-radiation thermometry. The report by Ehrler (1973) of an inverse, linear relationship between VPD and leafair temperature difference $\left(T_{1}-T_{a}\right)$ for well-watered cotton

Received for publication 31 May 1991. Accepted for publication 16 Dec. 1991 H/LA Paper no. 91-3, College of Agriculture and Home Economics Research Center, Washington State Univ., Pullman. Supported in part by a grant from the Massey Univ. Research Fund, New Zealand. Mention of trade names does not constitute a guarantee or warranty of the products by Washington State Univ. or Massey Univ., nor does it imply endorsement over similar commercial products. The cost of publishing this paper was defrayed in part by the payment of page charges. Under postal regulations, this paper therefore must be hereby marked advertisement solely to indicate this fact.

'Postdoctoral Fellow. Current address: Dept. of Horticulture and Landscape Architecture, Washington State Univ., Pullman, WA 99164-6414.

Professor. Current address: Charles Sturt Univ., P.O. Box 588, Wagga Wagga, New South Wales 2650, Australia.

${ }^{3}$ Graduate Student. established the basis for canopy temperature water-stress indices. Similar relationships have been established for alfalfa (Medicugo sativa L.), soybean [Glycine max (L.) Merr.], and squash (Cucurbita pepo L.) (Idso et al., 1981).

Several crop water stress indices based on $T_{C}-T_{a}$ have been proposed: 1) the SDD, defined as the accumulation of positive $\mathrm{T}_{\mathrm{C}}-\mathrm{T}_{\mathrm{a}}$ measured near solar noon (Idso et al., 1977; Jackson et al., 1977); 2) the TSD, defined as the difference in $\mathrm{T}_{c}$ between well-watered and water-stressed plots (Gardner et al., 1981); and 3) the CTV index, defined as the range of $\mathrm{T}_{C} \mathrm{~s}$ within a field (Clawson and Blad, 1982). An energy-balance approach, with surface temperature expressed as a function of $\mathrm{R}_{\mathrm{n}}$ and VPD (Monteith and Szeicz, 1962), has been used to develop a temperature-based CWSI (Jackson et al., 1981). The CWSI is based on well-established theoretical principles and is equivalent to the ET deficit.

Most of the research that has contributed to the development of these T.-based water stress indices was conducted on field crops with uniform canopies and exposed to VPDS up to 5 to 6 kpa (Idso et al., 1981). Attempts to adapt these principles to fruit trees have achieved mixed results (Syvertsen and Albrigo, 1980). Evans et al. (1982), working at VPDS from 0.2 to 2.0 $\mathrm{kPa}$, and Tormann (1986) found that there were inverse, linear relationships between VPD and $T_{c}-T_{a}$ for irrigated, shaded apple leaves and both shaded and sunlit nectarine [Prunus persica (L.) Batsch] leaves, respectively. Glenn et al. (1989) fitted a quadratic function to the relationship between VPD (1-4 kPa) and $\mathrm{T}_{c}-\mathrm{T}_{\mathrm{a}}$ for irrigated peaches. They did not report, however, either soil or plant water status. The ranges of reported VPDS were 0.2 to $2.0 \mathrm{kPa}$ and 1 to $4 \mathrm{kPa}$ by Evans et al. (1982) and Glenn et al. (1989), respectively.

The objective of our research was to evaluate canopy temperature-based and IR thermometer measurements of apple trees

Abbreviations: A, alfalfa; CWSI, crop water stress index; CTV, canopy-temperature-variability; D, drainage; ET, evapotranspiration; FI, full irrigation; H, herbicide strip; I, irrigation, IR, infrared $P$, black plastic mulch; $R_{n}$, net radiation; SDD, stress-degree-day; SW, short wave; TSD, temperature-stressday; VPD, vapor pressure deficit; WI, withheld irrigation. 
grown under deficit irrigation in a humid climate. $T_{c}-T_{a}$ measurements were compared with point measurements of $T_{1}$ $-\mathrm{T}_{\mathrm{a}}$, soil water storage, and VPD.

\section{Materials and Methods}

The research was conducted in 1989-90 on a two-row block of 'Royal Gala' apple trees on MM. 106 rootstock. The trees were planted $2.0 \times 4.5 \mathrm{~m}$ (1111 trees/ha) in 1985 and trained to a vertical-axis, central-leader system. The orchard soil is a Manawatu fine sandy loam with a textural change $0.6 \mathrm{~m}$ beneath the soil surface from a fine sandy loam B horizon to a gravelly coarse sand $\mathrm{C}$ horizon. This textural interface has been shown to impede water transport, yet water drains more freely below (Clothier et al., 1977a, 1977b). This soil type is prevalent in our region of New Zealand and has been observed to restrict root activity of maize (Zea mays L.) and pasture grass to the horizons above the gravelly coarse sand (B.E. Clothier, personal communication).

A deficit irrigation, orchard-floor management systems trial was initiated in 1987 using a split-block design. Each tree row consisted of three orchard-floor system subblocks randomized within two irrigation treatment main blocks. Both FI and WI treatments were applied within each row. Each of the 12 plots consisted of five trees. The three orchard-floor systems were 2 $\mathrm{m}$ wide, within-row: $\mathrm{H}, \mathrm{P}$, and A groundcover (Medicago sativa L. CV. As13R). Sod was planted between the rows. Commercial methods of fertilization and pest management were applied. A full crop developed and was harvested.

Irrigation volumes were calculated using a conservation of water equation (Sharma, 1985):

$$
\mathrm{P}+\mathrm{I}=\mathrm{ET}+\mathrm{RO}+\Delta \mathrm{G}^{\prime}+\Delta \mathrm{W}+\mathrm{D}
$$

where $\mathrm{P}$ is precipitation, I is irrigation, ET is evapotranspiration, $\mathrm{RO}$ is surface runoff, $\Delta \mathrm{G}^{\prime}$ is the change in the groundwater storage, $\Delta \mathrm{W}$ is the change in the soil water, and $\mathrm{D}$ is drainage out of the defined volume. It was assumed that RO, $\Delta \mathrm{G}^{\prime}$, and D were negligible, so Eq. [1] was simplified and solved for I:

$$
\mathrm{I}=\mathrm{ET}+\Delta \mathrm{W}-\mathrm{P}
$$

Daily irrigation volumes were based on means of the previous week's ET, $\Delta \mathrm{W}$, and $\mathrm{P}$.

ET for well-watered apple trees was estimated using a panevaporation method that employs a pan coefficient to calculate reference crop ET and then a crop coefficient specific to apples to calculate the crop ET (Doorenbos and Pruitt, 1977). The actual ET of the WI plots was calculated from AW and P between 1 Nov. 1989 and 8 Jan. 1990. Class A pan evaporation and precipitation data were obtained from a weather station $\approx 1$ $\mathrm{km}$ from the orchard.

The $\Delta \mathrm{W}$ was calculated from neutron hydroprobe (Model 503DR; CPN Corp., Martinez, Calif.) measurements made in two aluminum access tubes per plot located $0.5 \mathrm{~m}$ from the trunks of two interior trees of each plot. The hydroprobe was calibrated by linear regression of volumetric water content of the soil on neutron probe count (Campbell and Campbell, 1982). Counts were made $0.2,0.4$, and $0.6 \mathrm{~m}$ beneath the soil surface. The rooting zone was assumed to consist of the top $0.6 \mathrm{~m}$ of the soil profile. Water contents in millimeters were calculated by multiplying the soil water content (grams $\mathrm{H}_{2} \mathrm{O}$ per $\mathrm{cm}^{3}$ soil) by depth factors of 300,200 , and $100 \mathrm{~mm}$ for the $0.2-, 0.4-$, and $0.6-\mathrm{m}$ depths, respectively. Soil water contents were converted to liters using a tree area of $4 \mathrm{~m}^{2} /$ tree.
The FI treatment was begun in Spring 1989 on 29 Nov. Irrigation was applied daily through four trickle emitters per tree, each rated at 4 liters.h ${ }^{-1}$ and located $\approx 0.5 \mathrm{~m}$ from the trunk. Irrigation was withheld from the WI plots until 30 Jan. 1990 when excess irrigation was applied to refill the soil profile, followed by irrigation at $100 \%$ ET for the remainder of the season. The soil water of these plots reached levels approaching field capacity within 4 days. After this time, the same irrigation volumes were applied to both the FI and WI plots.

The quantity of soil water at field capacity was estimated to be $176 \mathrm{~mm}$ in the upper $0.6 \mathrm{~m}$ of the soil profile, based on neutron hydroprobe measurements made 2 to 3 days after rainfall (G. Durand, personal communication). The quantity of soil water at $-0.1 \mathrm{MPa}$, defined as the stress point, was estimated to be $105 \mathrm{~mm}$ in the top $0.6 \mathrm{~m}$, which was calculated from a water retention curve (G. Durand, personal communication) using a soil water extraction plate at $0.1 \mathrm{MPa}$. The readily extractable soil water fraction $\left(\theta^{\prime}\right)$ was calculated as:

$$
\theta^{\prime}=\frac{\mathrm{W}-\mathrm{W}_{\mathrm{sp}}}{\mathrm{W}_{\mathrm{fc}}-\mathrm{W}_{\mathrm{sp}}}
$$

where $\mathrm{W}$ is soil water content, $\mathrm{W}_{\mathrm{fc}}$ is soil water content at field capacity, and $\mathrm{W}_{\mathrm{sp}}$ is soil water content at the stress point (Ritchie, 1981). Thus, 6' of 1.0 equates to field capacity, while $\theta$ of zero indicates the stress point.

Leaf temperature $\left(T_{1}\right), T_{1}-T_{a}, T_{e}$, and $T_{c}-T_{a}$ measurements were made with an IR thermometer (Model 210; Everest Interscience, Fullerton, Calif.) at an emissivity setting of 0.98 . The viewing angle of the thermometer was $20^{\circ}$ and its spectral response range was 8 to $14 \mu \mathrm{m}$. Measurements were made on 14 Nov.; 1, 14, 21, and 28 Dec.; 2 Jan.; and 6 Mar. in 1989 and 1990 at solar noon $\pm 2 \mathrm{~h}$. Fruit were harvested following the 6 Mar. measurement date. The two or three interior trees in each plot were measured. The $\mathrm{T}_{\mathrm{C}}-\mathrm{T}_{\mathrm{a}}$ and $\mathrm{T}_{\mathrm{C}}$ measurements for each tree were made with the IR thermometer oriented at a solar zenith angle of $90^{\circ}, 2 \mathrm{~m}$ from the tree and $\approx 1.5 \mathrm{~m}$ above the ground. Thus, $T_{\mathrm{c}}$ measurements integrated $\approx 0.4 \mathrm{~m}^{2}$ of canopy surface area. Measurements were made from each of the four cardinal directions and averaged. The $\mathrm{T}_{1}-\mathrm{T}_{\mathrm{a}}$ and $\mathrm{T}_{1}$ measurements were made on two or three shaded $\left(\mathrm{T}_{\text {shl }}-\mathrm{T}_{\mathrm{a}}\right.$ and $\mathrm{T}_{\text {shl }}$, respectively) and sunlit $\left(\mathrm{T}_{\text {sul }}-\mathrm{T}_{\mathrm{a}}\right.$ and $\mathrm{T}_{\text {sul }}$, respectively) leaves per tree, with the IR thermometer $\approx 0.1 \mathrm{~m}$ from the adaxial leaf surface and viewing $\approx 10 \mathrm{~cm}^{2}$ of leaf surface area. VPDs were determined from wet- and dry-bulb temperatures obtained from a sling psychrometer before the IR-thermometry measurements of each plot. Psychrometer measurements were taken in a shaded location within the tree canopy $\approx 1 \mathrm{~m}$ above the ground.

The CWSI was calculated from equations developed by Jackson et al. (1981). The maximum theoretical CWSI for a waterstressed crop, assuming that the canopy resistance $\left(\mathrm{r}_{\mathrm{c}}\right) \rightarrow \infty$, was:

$$
T_{c}-T_{a}=\frac{r_{a} R_{n}}{\rho c_{p}}
$$

where $r_{a}$ is the aerodynamic resistance $\left(s \cdot m^{-1}\right), R_{n}$ is net radiation $\left(\mathrm{W} \cdot \mathrm{m}^{-2}\right), \mathrm{p}$ is the density of air $\left(\mathrm{kg} \cdot \mathrm{m}^{-3}\right)$, and $\mathrm{c}_{\mathrm{p}}$ is the specific heat capacity of air $\left(\mathrm{J} \cdot \mathrm{kg}^{-1} \cdot \mathrm{K}^{-1}\right)$. The minimum CWSI for a well-watered crop, assuming that the $r_{c} \rightarrow 0$, was:

$$
T_{c}-T_{a}=\frac{r_{a} R_{n}}{\rho c_{p}} \cdot \frac{\gamma}{s+\gamma}-\frac{e_{s}-e_{a}}{s+\gamma}
$$


where $\gamma$ is the psychometric constant $\left(\mathrm{Pa} \cdot \mathrm{K}^{-1}\right), \mathrm{s}$ is the slope of the saturation vapor pressure-temperature curve $\left(\mathrm{Pa} \cdot \mathrm{K}^{-1}\right)$, $\mathrm{e}_{\mathrm{s}}$ is the saturation vapor pressure $(\mathrm{Pa})$ at $\mathrm{T}_{\mathrm{a}}$, and $\mathrm{e}_{\mathrm{a}}$ is the vapor pressure.

Maximum $\mathrm{R}_{\mathrm{n}}, 440 \mathrm{~W} \cdot \mathrm{m}^{-2}$ in midsummer, was estimated by first calculating the shortwave (SW) solar radiation (Q) from the Angstrom equation, using coefficients derived for New Zealand (DeLisle, 1966):

$$
\mathrm{Q}=\left(0.28+0.51 \frac{\mathrm{n}}{\mathrm{N}}\right) \mathrm{Q}_{\mathrm{e}}
$$

where $\mathrm{n}$ is the bright sunshine' hours per day, $\mathrm{N}$ is the maximum possible sunshine hours per day, and $\mathrm{Q}_{\mathrm{e}}$ is the extraterrestrial $\mathrm{SW}$ radiation above the earth's atmosphere. Assuming bright sunshine all day $\frac{\mathbf{n}}{\overline{\mathbf{N}}}=1$, and with $\mathrm{Q}_{\mathrm{e}}=851 \mathrm{~W} \cdot \mathrm{m}^{-2}$ for December at lat $40 \%, \mathrm{Q}$ is $673 \mathrm{~W} \cdot \mathrm{m}^{-2}$. $\mathrm{R}_{\mathrm{n}}$ was then calculated using an equation derived by Proctor et al. (1972):

$$
\mathrm{R}_{\mathrm{n}}=0.80 \mathrm{Q}-98 \mathrm{~W} \cdot \mathrm{m}^{-2}
$$

For calculation of Eq. [4] and Eq. [5], $\mathrm{r}_{\mathrm{a}}$ was assumed to be $10 \mathrm{~s} \cdot \mathrm{m}^{-1}\left(\right.$ Jarvis, 1981) and $\mathrm{T}_{\mathrm{a}}$ was to be $25 \mathrm{C}$, with $\mathrm{pc}_{\mathrm{P}}=$ $1200 \mathrm{~J} \cdot \mathrm{m}^{-3} \cdot \mathrm{s}^{-1}\left(\mathrm{~J} \cdot \mathrm{s}^{-1}=\mathrm{W}\right)$. Solving Eq. [4] for the upper baseline, $\mathrm{T}_{\mathrm{C}}-\mathrm{T}_{\mathrm{a}}=3.7 \mathrm{C}$. Solving Eq. [5] for the lower baseline:

$$
\mathrm{T}_{\mathrm{c}}-\mathrm{T}_{\mathrm{a}}=1.0-3.9 \mathrm{VPD}(\mathrm{kPa})
$$

where VPD $=\mathrm{e}_{\mathrm{s}}-\mathrm{e}_{\mathrm{a}}$. The CWSI was calculated as the fraction of the difference between the measured and lower baseline $T_{C}$ $-\mathrm{T}_{\mathrm{a}} \mathrm{s}$ to the difference between the upper and lower baseline $\mathrm{T}_{\mathrm{C}}-\mathrm{T}_{\mathrm{a}} \mathrm{s}$ at the measured VPD (Jackson, 1982). The ratio of actual to potential ET (ET : $\left.\mathrm{ET}_{\mathrm{p}}\right)$ is defined as $1-\mathrm{CWSI}$ (Jackson et al., 1981).

Midday bulk leaf water potentials $\left(\psi_{\text {leaf }}\right)$ were measured on 26 Dec. 1989 and 2 and 9 Jan. 1990 using a pressure chamber (Model 3005; Soil Moisture Equipment Corp., Santa Barbara, Calif.).

\section{Results}

There was a significant interaction among all factors-dates, irrigation treatment, orchard-floor management system, and blocks-in determining soil water content of the top $0.6 \mathrm{~m}$ of the soil profile. The mean soil water content declined from field capacity to $31 \%$ of readily extractable soil water by $1 \mathrm{Dec}$. for all orchard-floor systems (Fig. 1). The readily extractable soil water of the $\mathrm{H}$ and $\mathrm{A}$ orchard floor systems under FI increased rapidly after irrigation began on 30 Nov. The soil water of $\mathrm{P}$ under FI, however, increased very slowly throughout the season. The soil water of the WI plots continued to decline until irrigation was restored to them on 30 Jan. The soil water of the $\mathrm{H}$ orchard floor system was $\approx 15 \%$ higher throughout the season than that of the other WI orchard-floor systems. On 6 Mar. the soil water was similar for all plots.

The calculated ET of both the $\mathrm{H}$ and A orchard floor plots of the WI treatment was $2.73 \mathrm{~mm} \cdot$ day $^{-1}$ between 1 Nov. 1989 and 8 Jan. 1990. The ET of the P treatment was only 1.04 $\mathrm{mm} \cdot$ day ${ }^{-1}$ for the same period.

The $\mathrm{T}_{1}-\mathrm{T}_{\mathrm{a}}$ of shaded leaves $\left(\mathrm{T}_{\mathrm{shl}}-\mathrm{T}_{\mathrm{a}}\right)$ was measured on all seven dates and, as expected, was significantly correlated with $\mathrm{T}_{\mathrm{C}}-\mathrm{T}_{\mathrm{a}}(r=0.71, \mathrm{n}=240)$. The linear regression equation was $\mathrm{T}_{\text {shl }}-\mathrm{T}_{\mathrm{a}}=1.0\left(\mathrm{~T}_{\mathrm{c}}-\mathrm{T}_{\mathrm{a}}\right)-0.7\left(r^{2}=0.50\right.$

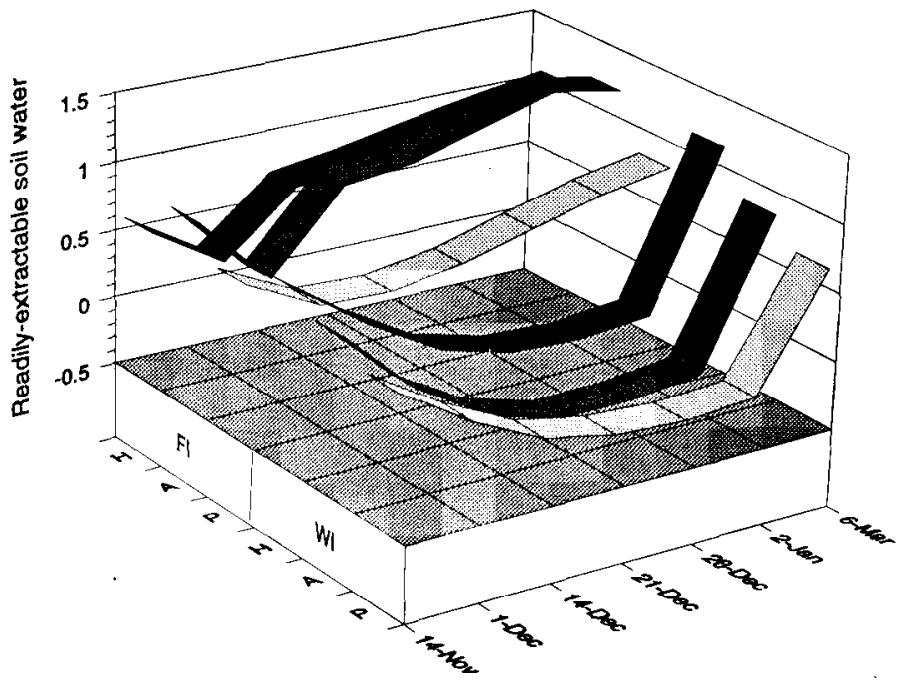

Fig. 1. Readily extractable soil water fraction $\left(\theta^{\prime}\right)$ for FI and WI treatments, and $\mathrm{H}, \mathrm{P}$, and A orchard-floor management systems on 14 Nov., 1, 14, 21, and 28 Dec. 1989, and 2 Jan. and 6 Mar. 1990. Theta values of 1 and $O$ represent soil water contents of 176 and 105 $\mathrm{mm}$, respectively. Each treatment/date represents the mean of measurements made in four neutron hydroprobe access tubes between 0.2 - and 0.6-m depths.

with $\mathrm{n}=240 ; \mathrm{F}_{\mathrm{reg}}=237$ with $\left.P<0.005\right)$, indicating that the temperatures of shaded leaves were $0.7 \mathrm{C}$ less than those of the canopy, which consists of both shaded and sunlit leaves.

The mean VPDS were $<0.5 \mathrm{kPa}$ on 14 Nov. and 1 Dec. but were $>1.0 \mathrm{kPa}$ on the other dates (Table 1). The widest range of VPDS were measured on 6 Mar.

The analysis of variance (ANOVA) of both $\mathrm{T}_{\mathrm{c}}-\mathrm{T}_{\mathrm{a}}$ and $\mathrm{T}_{\mathrm{shl}}$ $-\mathrm{T}_{\mathrm{a}}$ were highly significant $(P<0.005)$ for irrigation treatments and dates but not significant for blocks or orchard-floor systems. Both the mean $\mathrm{T}_{\mathrm{c}}-\mathrm{T}_{\mathrm{a}}$ and $\mathrm{T}_{\text {shl }}-\mathrm{T}_{\mathrm{a}}$ of the FI plots were significantly lower than those of the WI plots on 21 and 28 Dec., 2 Jan., and 6 Mar. (Table 1).

Linear regression of $\mathrm{T}_{\mathrm{c}}-\mathrm{T}_{\mathrm{a}}$ and $\mathrm{T}_{\mathrm{shl}}-\mathrm{T}_{\mathrm{a}}$ against VPD for the FI treatment accounted for a very small amount of the variation in $\mathrm{T}_{\mathrm{c}}-\mathrm{T}_{\mathrm{a}}\left(r^{2}=0.04\right.$ for $\mathrm{T}_{\mathrm{c}}-\mathrm{T}_{\mathrm{a}} \mathrm{vs}$. VPD and $r^{2}=$ 0.17 for $\mathrm{T}_{\text {shl }}-\mathrm{T}_{\mathrm{a}} \mathrm{vs}$. VPD). When $\mathrm{T}_{\mathrm{c}}-\mathrm{T}_{\mathrm{a}}$ and $\mathrm{T}_{\mathrm{shl}}-\mathrm{T}_{\mathrm{a}}$ were regressed against VPD for each measurement date, the slopes of the linear regression equations changed negative on the early dates to positive slopes and then back to a negative slope on the last date (Table 1). In addition to $\mathrm{T}_{\mathrm{c}}-\mathrm{T}_{\mathrm{a}}$ and $\mathrm{T}_{\mathrm{shl}}$ $-T_{a}, T_{\text {sul }}-T_{a}, T_{c}, T_{\text {shl }}$, and $T_{1}$ of sunlit leaves $\left(T_{\text {sul }}\right)$ were measured on 6 Mar. As expected, $\mathrm{T}_{\text {shl }}-\mathrm{T}_{\mathrm{a}}$ and $\mathrm{T}_{\text {sul }}-\mathrm{T}_{\mathrm{a}}$ were correlated with $\mathrm{T}_{\mathrm{C}}-\mathrm{T}_{\mathrm{a}}$, and $\mathrm{T}_{\text {shl }}$ and $\mathrm{T}_{\text {sul }}$ were correlated with $\mathrm{T}_{c}$ (Table 2). All of these measures of canopy and leaf temperatures, except $\mathrm{T}_{\text {sul }}$, were correlated with VPD; however, only $\mathrm{T}_{\mathrm{c}}-\mathrm{T}_{\mathrm{a}}, \mathrm{T}_{\mathrm{shl}}-\mathrm{T}_{\mathrm{a}}$, and $\mathrm{T}_{\mathrm{sul}},-\mathrm{T}_{\mathrm{a}}$ showed negative correlations.

When $T_{c}-T_{2}$ was regressed against $\theta^{\prime}$ for both FI and WI treatments on 14, 21, and 28 Dec. and 2 Jan., the linear regression equation was $\mathrm{T}_{\mathrm{c}}-\mathrm{T}_{\mathrm{a}}=0.87-0.77 \theta '\left(r^{2}=0.30\right.$ with $\mathrm{n}=48 ; \mathrm{F}_{\mathrm{reg}}=19.7$ with $P<0.005$ ) (Fig. 2). These were the dates in which the differences in soil water were greatest between the FI and WI plots (Fig. 1). A logarithmic transformation improved this relationship only slightly, with $\mathrm{T}_{\mathrm{C}}-\mathrm{T}_{\mathrm{a}},=0.83$ $-1.04\left(\ln \theta^{\prime}+1\right)\left(r^{2}=0.31 ; \mathrm{F}_{\mathrm{reg}}=20.3\right)$.

When the $\mathrm{T}_{\mathrm{c}}-\mathrm{T}_{\mathrm{a}} \mathrm{s}$ for the WI treatment were plotted against VPDs for 14, 21, and 28 Dec. and 2 Jan., all but one point fell 
Table 1. The mean and range of VPD, the mean canopy- and leaf-air temperature differences for shaded leaves $\left(T_{c}-T_{a}\right.$ nd $T_{c h} T_{a}$ respectively) for FI and WI, respectively, the slopes of the linear regression equations between $\mathrm{T}_{\mathrm{c}}-\mathrm{T}_{\mathrm{a}}$ and VPD for the FI treatment, and the CWSI for the WI treatment for seven dates in 1989-90.

\begin{tabular}{|c|c|c|c|c|c|c|c|c|c|}
\hline \multirow[b]{2}{*}{ Date } & \multicolumn{2}{|c|}{ VPD $(\mathrm{kPa})^{\mathrm{z}}$} & \multicolumn{2}{|c|}{$\mathrm{T}_{\mathrm{c}}-\mathrm{T}_{\mathrm{a}}\left({ }^{\circ} \mathrm{C}\right)^{\mathrm{y}}$} & \multicolumn{2}{|c|}{$T_{\text {shl }}-T_{a}\left({ }^{\circ} \mathrm{C}\right)^{y}$} & \multicolumn{2}{|c|}{ Slope $\left({ }^{\circ} \mathrm{C} / \mathrm{kPa}\right)^{x}$} & \multirow[b]{2}{*}{$\mathrm{CWSI}^{\mathrm{w}}$} \\
\hline & Mean & Range & $\mathrm{FI}$ & WI & $\mathrm{FI}$ & WI & $T_{c}-T_{a}$ & $\mathrm{~T}_{\mathrm{shl}}-\mathrm{T}_{\mathrm{g}}$ & \\
\hline $\begin{array}{l}14 \text { Nov. } \\
1 \text { Dec. } \\
14 \text { Dec. } \\
21 \text { Dec. } \\
28 \text { Dec. } \\
2 \text { Jan. } \\
6 \text { Mar. } \\
\text { LSD }_{0.05} \\
\text { LSD }_{0.0}\end{array}$ & $\begin{array}{l}0.46 \\
0.42 \\
1.06 \\
1.40 \\
1.29 \\
1,10 \\
1.61\end{array}$ & $\begin{array}{l}0.24-0.62 \\
0.23-0.54 \\
0.92-1.28 \\
1.29-1.60 \\
1.18-1.39 \\
0.85-1.22 \\
0.94-2.26\end{array}$ & $\begin{array}{r}0.3 \\
1.0 \\
0.4 \\
0.3 \\
0.5 \\
-0.5 \\
0.1 \\
0 \\
0\end{array}$ & $\begin{array}{l}0.3 \\
1.2 \\
0.9 \\
1.6 \\
1.1 \\
0.4 \\
1.4\end{array}$ & $\begin{array}{r}0.0 \\
0.9 \\
0.4 \\
-0.4 \\
0.2 \\
-2.4 \\
-1.5\end{array}$ & $\begin{array}{r}0.0 \\
1.1 \\
0.8 \\
1.0 \\
0.9 \\
-1.6 \\
-0.1\end{array}$ & $\begin{array}{r}-2.8(0.10) \\
-2.0(0.27) \\
0.9(0.03) \\
2.0(0.07) \\
10.8(0.55) \\
2.6(0.08) \\
-2.7(0.62)\end{array}$ & $\begin{array}{r}-3.0(0.11) \\
-2.0(0.38) \\
0.0(0.00) \\
3.0(0.06) \\
10.8(0.48) \\
6.8(0.47) \\
-2.8(0.58)\end{array}$ & $\begin{array}{l}0.26 \mathrm{c} \\
0.42 \mathrm{~b} \\
0.42 \mathrm{~b} \\
0.77 \mathrm{a} \\
0.66 \mathrm{a} \\
0.51 \mathrm{~b} \\
0.74 \mathrm{a}\end{array}$ \\
\hline
\end{tabular}

${ }^{2}$ Determined from wet- and dry-bulb temperatures measured with a sling psychrometer, $1 \mathrm{~m}$ above the ground in the shade.

${ }^{y}$ Mean separation by protected LSD. Data shown are means of 18 observations.

${ }^{x}$ Values in parentheses are the coefficients of determination $\left(r^{2}\right)$.

"Mean separation by Tukey's $w$ procedure, $P \leq 0.05$.

Table 2. Correlation coefficients of canopy-air temperature $\left({ }^{\circ} \mathrm{C}\right)$ differences $\left(\mathrm{T}_{\mathrm{c}}-\mathrm{T}_{\mathrm{a}}\right)$, leaf-air temperature differences $\left({ }^{\circ} \mathrm{C}\right)$ of shaded and sunlit leaves $\left(\mathrm{T}_{\text {sth }}-\mathrm{T}_{\mathrm{a}}\right.$ and $\mathrm{T}_{\mathrm{sul}}-\mathrm{T}_{\mathrm{a}}$, respectively), canopy temperatures $\left[\mathrm{T}_{\mathrm{c}}\left({ }^{\circ} \mathrm{C}\right)\right]$, and leaf temperatures (" $\mathrm{C}$ ) of shaded and sunlit leaves ( $\mathrm{T}_{\text {shl }}$ and $\mathrm{T}_{\text {sul }}$, respectively), and VPD $(\mathrm{kPa})$ for 6 Mar. 1990.

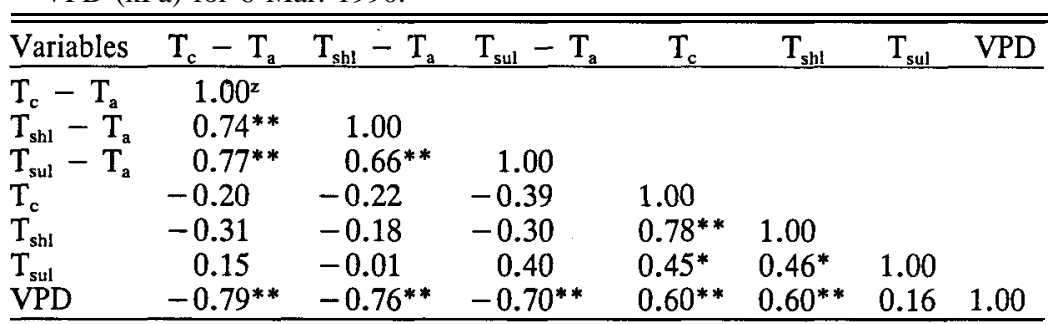

${ }^{2}$ Correlation coefficients calculated by Pearson's product-moment method $(\mathrm{n}=$ 24).

*,** Significant values of $r$ at $P \leq 0.05$ and $P \leq 0.01$, respectively.

between the upper and lower baselines derived via the energybalance equation (Fig. 3). An ANOVA of CWSI indicated that there were significant differences between these dates (Table 1). The CWSI initially decreased, but then decreased as the period without irrigation continued.

The WI-A treatment consistently had the lowest bulk $\psi_{\text {leaf }}$ of $-1.78 \mathrm{kPa}$, compared with -1.46 and $-1.55 \mathrm{kPa}$ for the WI$\mathrm{H}$ and WI-P treatments, respectively. All of the FI orchardfloor systems had higher $\psi_{\text {leaf }}$ than the WI systems, with a mean of $-1.16 \mathrm{kpa}$.

\section{Discussion}

The A orchard-floor system had a slightly higher soil water content than did the $\mathrm{H}$ system, despite both treatments receiving the same quantity of irrigation (Fig. 1). Larger soil water deficits and ET have been reported for alfalfa relative to pasture grasses in New Zealand (Hayman and McBride, 1984) and in the Great Plains of the United States (Blad and Rosenberg, 1974), respectively. Therefore, the higher soil water content for A reported here may be due to an improved water-holding capacity and/or neutrons from the hydroprobe reacting with the $\mathrm{H}^{+}$of the additional organic matter provided by A. An improved waterholding capacity would be expected to reduce drainage and loss of applied irrigation below the root zone. The soil water of the $P$ orchard-floor system increased slowly under FI (Fig. 1). This result suggests that precipitation was a major contributor to the soil water of the $\mathrm{H}$ and A treatments. Between 14 Nov. 1989 and 6 Mar. 1990, $195 \mathrm{~mm}$ of precipitation fell. The soil water of the $\mathrm{H}$ and A plots in which irrigation was withheld, however, declined from 30 Nov. until 28 Dec. During this period $45 \mathrm{~mm}$ of precipitation fell. Apparently precipitation was an insufficient supplement to irrigation to increase rapidly the soil water of the $\mathrm{H}$ and $\mathrm{A}$ orchard-floor systems.

The WI-H treatment had a higher soil water content than the other systems (Fig. 1). Again, precipitation probably accounted for the increased soil water of $\mathrm{H}$ over that of $\mathrm{P}$. The lowest soil water content of the A plots during withholding of irrigation was probably the result of greater ET, as has been shown previously (Black and Mitchell, 1970). Therefore, despite irrigation being withheld, precipitation was sufficient to maintain more soil water in $\mathrm{H}$ than $\mathrm{P}$, yet was insufficient to overcome the apparently higher ET of the A plots. On 6 Mar., after more than a month of full irrigation, the WI-A treatment had more soil water than P (Fig. 1). This finding again supports the argument for greater water-holding capacity provided by three seasons of alfalfa cultivation.

The CWSI decreased after the 0.77 maximum on 21 Dec. 1989 (Table 1), despite the continued low soil-water availability through 2 Jan. 1990 (Fig. 1). Variations in wind speed could have contributed to these anomalies. Greater wind speeds (u) 


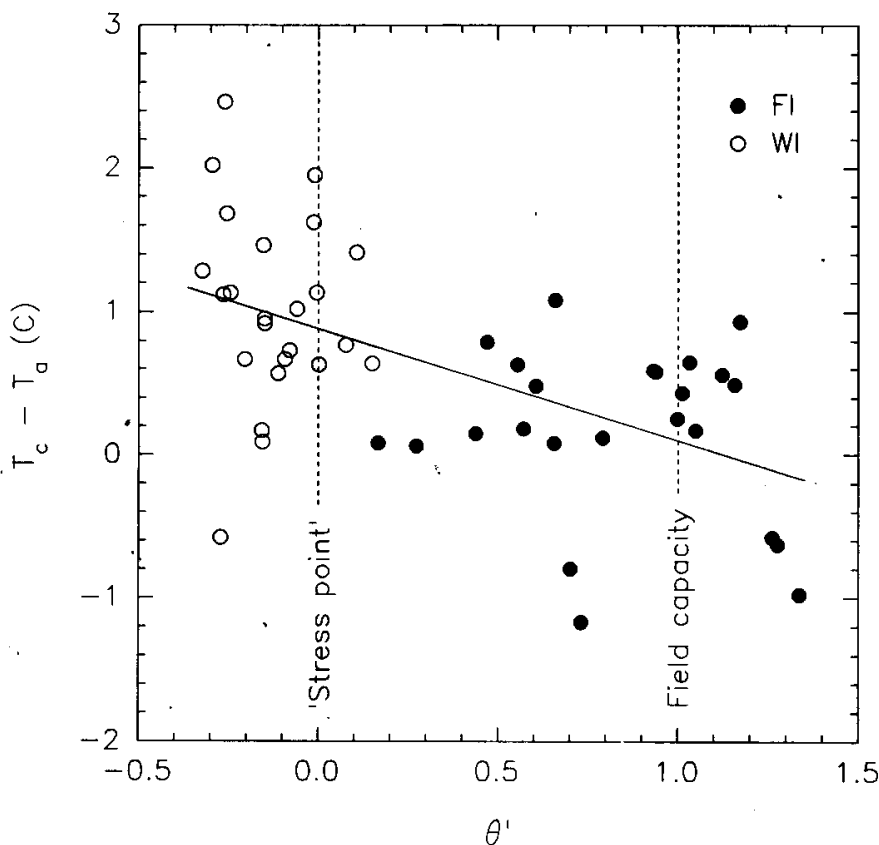

Fig. 2. Relationship between the mean canopy-air temperature difference $\left(T_{c}-T_{a}\right)$ and the readily extractable soil-water fraction $\left(\theta^{\prime}\right)$ for each plot of the FI and WI treatments on 14, 21, and 28 Dec. 1989, and 2 Jan. $1990\left(\mathrm{~T}_{\mathrm{c}}-\mathrm{T}_{\mathrm{a}}=0.87-0.77 \theta \quad ; r^{2}=0.30\right)$. The $\theta$ ' at field capacity $(-0.01 \mathrm{MPa})$ and the stress point $(-0.1$ $\mathrm{MPa}$ ) are shown.

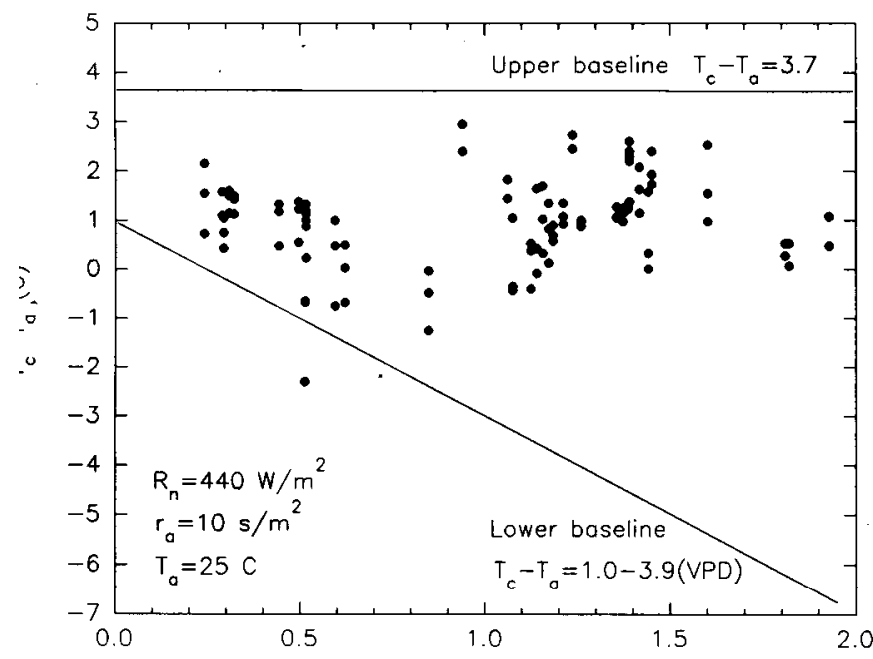

Fig. 3. Relationship between the canopy-air temperature difference $\left(\mathrm{T}_{\mathrm{c}}-\mathrm{T}_{\mathrm{a}}\right)$ and VPD for the WI treatment on 14 Nov., 1, 14, 21, and 28 Dee, 1989, and 2 Jan. and 6 Mar. 1990. The upper and lower baselines are represented by the equations $\mathrm{T}_{\mathrm{c}}-\mathrm{T}_{\mathrm{a}}=3.7 \mathrm{C}$ and $\mathrm{T}_{\mathrm{c}}-\mathrm{T}_{\mathrm{a}}=1.0-3.9(\mathrm{VPD})$, respectively.

within the canopy would be expected from directions not adjacent to other trees, i.e., from the $\mathrm{W}$ and $\mathrm{E}$. Increased $\mathrm{u}$ would reduce $r_{a}$ (Campbell, 1977), and, consequently $T_{c}-T_{a}$ (Eqs. [4] and [5]). Although u was not measured within the orchard, daily wind runs were recorded at the weather station $1 \mathrm{~km}$ away. When daily wind runs were converted to mean wind speed $(\bar{u})$ $\left(\mathrm{km} \cdot \mathrm{day}^{-1} / 86.4=\mathrm{m} \cdot \mathrm{s}^{-1}\right), \quad$ waried from $1.9 \mathrm{~m} \cdot \mathrm{s}^{-1}$ on 14 Nov. to $5.6 \mathrm{~m} \cdot \mathrm{s}^{-1}$ on 1 Dec. 1989 , with moderate to strong winds ( 2 to $8 \mathrm{~m} \cdot \mathrm{s}^{-1}$ ) on all other measurement dates (Doorenbos and Pruitt, 1977). As the research plots were situated $\approx 100$ m downwind of a 15- to 20-m-high natural windbreak, an effect of the windbreak on the windspeed profile within the orchard canopy would still be manifested (Campbell, 1977). O'Toole and Hatfield (1983) observed oscillations in the foliage-to-air temperature differentials of sorghum [Sorghum bicolor (L.) Moench], corn, and bean (Phaseolus vulgaris L.) caused by fluctuations in the foliage temperature. They stated that these oscillations were caused by interactions between wind and convective currents above the canopy. Fluctuations in $\mathrm{T}_{\mathrm{c}}-\mathrm{T}_{\mathrm{a}}$ due to varying windspeeds could cause erroneous CWSI values, with the CWSI being artificially low at high windspeeds. This artifact could lead to a failure to recognize water stress conditions and a delay in irrigation (O'Toole and Hatfield, 1983).

Changes in radiation, due to variations in cloud cover, also can affect canopy temperature. Pennington and Heatherly (1989) found a direct relationship between $\mathrm{T}_{c}-\mathrm{T}_{a}$ and $\mathrm{Q}$ for cotton and soybean, with transient changes occurring in only 20 to 25 sec. The slope of this relationship also varied with the degree of water stress of the crop. In Denmark, Jensen et al. (1990) found that the $T_{c}-T_{a}$ of rape (Brassica napus $L$.) varied with Q, causing variation in the lower baseline equation (Eq. [5]) of the CWSI. VPD also affects the CWSI, with lower VPD resulting in Eq. [5] having a lesser slope than when the VPD is high (Kirkham et al., 1983).

In the present study, significant variation in the slope of $T_{c}$ $-\mathrm{T}_{\mathrm{a}}$ (Eq. [5]) was found (Table 1). This variation appeared to be independent of whether the canopy or shaded leaves were measured, suggesting that $\mathrm{Q}$ was not a significant factor in this variation. Theoretical calculations of the effect of humidity on the upper and lower baseline equations (Eqs. [4] and [5], respectively), however, indicate that as relative humidity (RH) approaches $100 \%$, the lower limit of $\mathrm{T}_{\mathrm{C}}$ approaches the upper limit of $\mathrm{T}_{\mathrm{c}}$ (Clawson et al., 1989). Although the lower limit of $\mathrm{T}_{\mathrm{C}}$ will still be 2 to $4 \mathrm{C}$ less than the upper limit of $\mathrm{T}_{\mathrm{c}}$ at $100 \%$ $\mathrm{RH}$, the difference between the two limits will be minimal. This relationship would be expected to increase the potential errors in the calculation of the CWSI.

The anomalously high CWSI of the WI plots on 6 Mar. 1990 was puzzling, especially after 35 days of FI (Table 1). O'Toole and Real (1986) observed variations in the slope of the lower baseline equation (Eq. [5]) from the vegetative to the postanthesis growth stages of rice (Oryza sativa $\mathrm{L}$.). They found these variations in slope to be due to increases in the $r_{c}$ to water vapor transport as the crop matured. The anomalous CWSI on 6 Mar. may be attributable to development changes in stomatal behavior as leaf senescence was approached (Field, 1987).

The CWSI requires the input of several parameters that may be difficult to evaluate. Fluctuations in $\mathrm{u}$ and $\mathrm{Q}$, the potential for increased errors in the calculation of CWSI baselines at low VPDS, and the possible changes in the response of the canopy to energy fluxes as the crop matures suggest that caution should be exercised in using IR thermometry-based, water-stress indices for irrigation scheduling in humid, temperate climates. The arguable validity of CWSI estimations also may be exacerbated in tree crops where canopy heterogeneity is common. In these crops, the IR thermometer may measure more than the surface temperature of the foliage; it may also measure perennial components of the tree and background objects if gaps exist in the foliage. Although Gardner et al. (1981) suggested that employing a well-watered reference crop largely overcomes the complications of fluctuating environmental factors, its use in this study did not provide enough sensitivity to establish satisfactorily accurate baselines (Table 1). The use of theoretical baselines (Fig. 3), however, improved the estimation of water 
stress by the CWSI (Table 1). As was illustrated on the 6 Mar. 1990 measurement date, with clear skies, light winds, and a wide range of VPDs, there was a significant correlation between $\mathrm{T}_{\mathrm{c}}-\mathrm{T}_{\mathrm{a}}$ and VPD (Table 2).

Campbell and Norman (1990) addressed the difficulties in estimating plant water status from canopy temperatures. They showed that $T_{c}-T_{a}$ is insensitive to increasing $r_{c}$ at low VPDs and that changing $\mathrm{u}$ has little effect on $\mathrm{T}_{\mathrm{c}}-\mathrm{T}_{\mathrm{a}}$. They suggested that baseline analysis be abandoned in favor of direct computation of $r_{c}$ by the Penman transformation (Campbell, 1977). In this way VPD, $\mathrm{R}_{\mathrm{n}}$, and ET will be taken fully into account, which is especially important in humid climates, where these factors are more variable than in dry climates and where errors in the CWSI may be as high as 0.10 to 0.15 (Campbell and Norman, 1990).

The CWSI may not always be a good predictor of plant water status, especially for heterogeneous canopies like fruit trees. In humid climates, soil water may be more reliable for predicting potential plant water stress and scheduling of irrigations.

\section{Literature Cited}

Black, J.D.F. and P.D. Mitchell. 1970. Soil water use from an apple orchard under various soil management systems. Austral. J. Expt. Agr. \& Animal Husbandry 10:209-213.

Blad, B.L. and N.J. Rosenberg. 1974. Evapotranspiration by subirrigated alfalfa and pasture in the east central Great Plains. Agron. J. 66:248-252.

Campbell, G.S. 1977. An introduction to environmental biophysics. Springer-Verlag, Berlin.

Campbell, G.S. and M.D. Campbell. 1982. Irrigation scheduling using soil moisture measurements: Theory and practice. Adv. Irr. 1:2541.

Campbell, G.S. and J.M. Norman. 1990. Estimation of plant water status from canopy temperature: An analysis of the inverse problem, p. 255-271. In: M.D. Steven and J.A. Clark (eds.). Applications of remote sensing in agriculture. Butterworths, London.

Chalmers, D.J., K.A. Olsson, and T.R. Jones. 1983. Water relations of peach trees and orchards, p. 197-232. In: T.T. Kozlowski (cd.). Water deficits and plant growth, vol. 7. Academic, New York.

Clawson, K.L. and B.L. Blad. 1982. Infrared thermometry for scheduling irrigation of corn. Agron. J. 74:311-316.

Clawson, K.L., R.D. Jackson, and P.J. Pinter, Jr. 1989. Evaluating plant water stress with canopy temperature differences. Agron. J. 81:858-863.

Clothier, B.E., D.R. Scotter, and J.P. Kerr. 1977a. Water retention in soil underlain by a coarse-textured layer: Theory and a field application. Soil Sci. 123:392-399.

Clothier, B.E., D.R. Scotter, and J.P. Kerr. 1977b. Drainage flux in permeable soil underlain by a coarse-textured layer. Soil Sci. Soc. Amer. J. 41:671-676.

DeLisle, J.F. 1966. Mean daily insolation in New Zealand. N.Z. J. Sci. 9:992-1005.

Doorenbos, J. and W.O. Pruitt. 1977. Guidelines for predicting crop water requirements. FAO Irr. and Drainage, 24. Food and Agr. Org., United Nations, Rome.

Ehrler, W.L. 1973. Cotton leaf temperatures as related to soil water depletion and meteorological factors. Agron. J. 65:404409.

Evans, R.G., D.L. Bassett, and E.L. Proebsting. 1982. Indicating water stress in apples using infrared thermometry. Proc. Amer. Soc. Agr. Eng. 82-2531.

Field, C.B. 1987. Leaf-age effects on stomatal conductance, p. 367-
384. In: E. Zeiger, G.D. Farquahar, and I.R. Cowan (eds.). Stomatal function. Stanford Univ. Press, Stanford.

Gardner, B.R., B.L. Blad, D.P. Garrity, and D.G. Watts. 1981. Relationships between crop temperature, grain yield, evapotranspiration and phonological development in two hybrids of moisture stressed sorghum. Irr. Sci. 2:213-224.

Glenn, D.M., J.W. Worthington, W.V. Welker, and M.J. McFarland. 1989. Estimation of peach tree water using infrared thermometry. J. Amer. Soc. Hort. Sci. 114:737-741.

Hayman, J.M. and S.D. McBride. 1984. The response of pasture and lucerne to irrigation. Technical Rpt. 17, Winchmore Irr. Res. Sta. Min. Agr. and Fisheries, Wellington, New Zealand.

Idso, S.B., R.D. Jackson, P.J. Pinter, Jr., R.J. Reginato, and J.L. Hatfield. 1981. Normalizing the stress-degree-day parameter for environmental variability. Agr. Meteorol. 24:45-55.

Idso, S.B., R.D. Jackson, and R.J. Reginato. 1977. Remote sensing of crop yields. Science 196:19-25.

Jackson, R.D. 1982. Canopy temperature and crop water stress. Adv. Irr. 1:43-85.

Jackson, R.D., S.B. Idso, R.J. Reginato, and P.J. Pinter, Jr. 1981. Canopy temperature as a crop water stress indicator. Water Resource Res. 17:1133-1138.

Jackson, R.D., R.J. Reginato, and S.B. Idso. 1977. Wheat canopy temperature: A practical tool for evaluating water requirements. Water Resource Res. 13:651-656.

Jarvis, P.G. 1981. Stomatal conductance, gaseous exchange, and transpiration, p. 175-204. In: J. Grace, E.D. Ford, and P.G. Jarvis (eds.). Plants and their atmospheric environment. Blackwell Scientific, Oxford.

Jensen, H.E., H. Svendsen, S.E. Jensen, and V.O. Mogensen. 1990. Canopy-air temperature of crops grown under different irrigation regimes in a temperature humid climate. Irr. Sci. 11:181-188.

Jones, H.G., A.N. Lakso, and J.P. Syvertsen. 1985. Physiological control of water status in temperate and subtropical fruit trees. Hort. Rev. 7:301-344.

Kirkham, M.B., D.E. Johnson, Jr., E.T. Kamemasu, and L.R. Stone. 1983. Canopy temperature and growth of differentially irrigated alfalfa. Agr. Meteorol. 29:235-246.

Monteith, J.L. and G. Szeicz. 1962. Radiative temperature in the heat balance of natural surfaces. Quarterly J. Royal Meteorol. Soc. 88:496 507.

O'Toole, J.C. and J.L. Hatfield. 1983. Effect of wind on the crop water stress index derived by infrared thermometry. Agron. J. 75:811817.

O'Toole, J.C. and J.G. Real. 1986. Estimation of aerodynamic and crop resistances from canopy temperature. Agron. J. 78:305-310.

Pennington, D.A. and L. Heatherly. 1989. Effects of changing solar radiation on canopy-air temperatures of cotton and soybean. Agr. For. Meteorol. 46:1-14.

Proctor, J.T.A., W.J. Kyle, and J.A. Davies. 1972. The radiation balance of an apple tree. Can. J. Bot. 50:1731-1740.

Ritchie, J.T. 1981. Soil water availability. Plant \& Soil 58:327-338.

Sharma, M.L. 1985. Estimating evapotranspiration. Adv. Irr. 3:213281.

Spomer, L.A. 1985. Techniques for measuring plant water. HortScience 20:1021-1028.

Syvertsen, J.P. 1985. Integration of water stress in fruit trees. HortScience 20:1039-1043.

Syvertsen, J.P. and L.G. Albrigo. 1980. Some effects of grapefruit tree canopy position on microclimate, water relations, fruit yield, and juice quality. J. Amer. Soc. Hort. Sci. 105:454-459.

Tormann, H. 1986. Canopy temperature as a plant water stress indicator for nectarines. S. Afr. J. Plant Soil 3:110-114. 